\title{
A 155K Acid Carboxypeptidase O from Aspergillus oryzae
}

\author{
Michio TAKEUCHI and Eiji ICHISHIMA \\ Laboratory of Enzymology and Microbial Chemistry, Tokyo Nōkō University, \\ Fuchu, Tokyo 183, Japan \\ Received September 3, 1985
}

\begin{abstract}
When Aspergillus oryzae IAM 2640 was grown in liquid medium, a high molecular weight acid CPase was produced exclusively in the medium. The enzyme was purified and characterized. The purified enzyme was homogeneous by PAGE at pH 9.4, by isoelectric focusing, and by FPLC, and its molecular weight was $155 \mathrm{~K}$ by gel filtration. When the $155 \mathrm{~K}$ enzyme was electrophoresed in SDS-polyacrylamide gel, a single band with a molecular weight of $73 \mathrm{~K}$ was obtained. The enzyme was inhibited by TPCK and PMSF but not IAA or PCMB. The $K m$ and $k_{\text {cat }}$ values of the enzyme for Z-Glu-Tyr, angiotensin, and bradykinin at $\mathrm{pH} 3.7$ and $30^{\circ} \mathrm{C}$ were $0.48 \mathrm{~mm}, 86 \mathrm{sec}^{-1}, 0.1 \mathrm{~mm}$, $0.34 \mathrm{sec}^{-1}$, and $0.06 \mathrm{~mm}, 14.7 \mathrm{sec}^{-1}$, respectively. The enzyme hydrolyzed proangiotensin and bradykinin sequentially at $\mathrm{pH} 3.7$ from their C-terminus. The enzyme shared an antigen with low molecular weight $A$. oryzae acid CPase O-1.
\end{abstract}

Acid CPases release most amino acid residues, including proline, from the $\mathrm{C}$ terminal of peptides and proteins at acidic pHs. Acid CPases have been isolated and purified from various sources such as

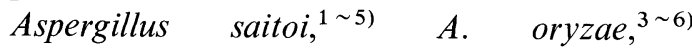
Penicillium janthinellum, ${ }^{7 \sim 11)} P$. roqueforti, ${ }^{12)}$ baker's yeast, ${ }^{13)}$ Neurospora crassa ${ }^{14)}$ Picnoporus sanguineus, ${ }^{15}$ ) citrus fruit and leaves ${ }^{16,17)}$ barley, ${ }^{18)}$ French beans, ${ }^{19)}$ and wheat bran. ${ }^{20)}$

Acid Cpases of $A$. oryzae are produced extracellularly on both solid bran and liquid cultures. We reported the purification and some properties of acid CPase O-1 and O-2 from $A$. oryzae IAM 2640. ${ }^{6}$ ) The two enzymes are identical in most properties and have a molecular weight of about $63 \mathrm{~K}$, but their action on substrates with Pro-X bonds and their isoelectric points differed.

We found that when $A$. oryzae IAM 2640 was grown in a liquid medium of $5 \%$ rice bran, the $155 \mathrm{~K}$ molecular weight acid CPase was produced exclusively.

\section{MATERIALS AND METHODS}

Materials. $N$-Acylpeptides, proangiotensin, angiotensin, and bradykinin were purchased from the Peptide Institute, Inc., Osaka. An isoelectric focusing column and Ampholine were obtained from LKB-Produkter $\mathrm{AB}$, Sweden. All other chemicals were of reagent grade.

Organism. A. oryzae IAM 2640 was used as the source of acid CPase. The strain was isolated by Sakaguchi and Yamada $^{21)}$ from sake-koji at Kyoto.

Acid CPase assay. The enzyme was assayed routinely with Z-Glu-Tyr in $50 \mathrm{~mm}$ sodium acetate buffer. One katal of the $155 \mathrm{~K}$ acid CPase $\mathrm{O}$ was defined as the amount of enzyme required to liberate one mol of tyrosine from $\mathrm{Z}$ -

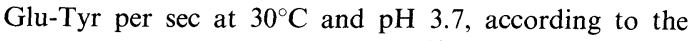
IUPAC and IUB recommendation. ${ }^{22}$ )

Protein measurement. Protein was measured by the absorbance at $280 \mathrm{~nm}\left(E_{1 \mathrm{~cm}, 280 \mathrm{~nm}}^{1 \%}=18.8\right)$ using a Shimadzu UV 100-02 spectrophotometer.

Submerged culture. For large-scale cultivation we used a 30-liter jar fermentor (Marubishi Co., Tokyo). One kg of

Abbreviations: CPase, carboxypeptidase; FPLC, fast protein liquid chromatography; C-, carboxy-; PAGE, polyacrylamide gel electrophoresis; Z-, benzyloxycarbonyl-; IAA, monoiodoacetic acid; PCMB, p-chloromercuribenzoate; TPCK, tosyl-phenylalanine chloromethyl ketone; PMSF, phenylmethylsulfonylfluoride; EDTA, ethylenediaminetetraacetate; S-PI, Streptomyces pepsin inhibitor. The abbreviations of amino acid residues denote the L-forms. 
rice bran and $100 \mathrm{~g}$ of $\mathrm{KH}_{2} \mathrm{PO}_{4}$ were added to 19 liters of tap water and the mixture was adjusted to $\mathrm{pH} 4.5$ with conc. $\mathrm{HCl}$. The medium was sterilized at $121^{\circ} \mathrm{C}$ for $30 \mathrm{~min}$ and inoculated with $400 \mathrm{ml}$ of seed culture. Cultivation was at $30^{\circ} \mathrm{C}$ with aeration of 10 liters $/ \mathrm{min}$ and agitation of $250 \mathrm{rpm}$ for $0 \sim 24 \mathrm{hr}$ and $400 \mathrm{rpm}$ for $24 \sim 72 \mathrm{hr}$. Seed cultures were cultivated in a 3-liter Sakaguchi flask containing the same medium inoculated with one platinum loop of spores for 2 days on a reciprocal shaker at $30^{\circ} \mathrm{C}$.

Purification of the enzyme. All steps were done at $4{ }^{\circ} \mathrm{C}$. The culture broth was filtered through a Toyo Glass filter type GC-90 and the culture filtrate was adjusted to $\mathrm{pH} 5.2$ with $2 \mathrm{~N} \mathrm{NaOH}$. An equal volume of cold ethanol (about $0^{\circ} \mathrm{C}$ ) was added to the culture filtrate. The resulting precipitate was collected by centrifugation at $8,000 \times g$, and lyophilyzed. The crude enzyme precipitate was extracted three times with $600 \mathrm{ml}$ of distilled water. The supernatant was then dialyzed against $0.005 \mathrm{~m}$ acetate buffer ( $\mathrm{pH}$ 5.0). Next the enzyme solution was put on DEAE-Sephadex A-50 column $(4 \times 50 \mathrm{~cm})$ that had been equilibrated with $0.005 \mathrm{M}$ acetate buffer $(\mathrm{pH} 5.0)$. The enzyme was eluted with an $\mathrm{NaCl}$ gradient $(0 \sim 0.2 \mathrm{M})$ in $0.005 \mathrm{M}$ acetate buffer, $\mathrm{pH} 5.0$, using a $500-\mathrm{ml}$ mixing chamber. The active fraction was then put on a column $(2 \times 60 \mathrm{~cm})$ of CM-Sephadex C-50 that had been equilibrated with $0.01 \mathrm{~m}$ acetate buffer, $\mathrm{pH} 4.0$. The enzyme was eluted with an $\mathrm{NaCl}$ gradient $(0 \sim 0.1 \mathrm{M})$ in $0.01 \mathrm{M}$ acetate buffer, $\mathrm{pH} 4.0$, using a $500-\mathrm{ml}$ mixing chamber. The active fraction was dialyzed against $0.01 \mathrm{~m}$ acetate buffer, $\mathrm{pH} 4.0$, and the dialyzed enzyme solution was put on a column $(2 \times 70 \mathrm{~cm})$ of SP-Sephadex C-50. Elution was done with $0.01 \mathrm{~m}$ acetate buffer $(\mathrm{pH} 4.0)$, by an increasing $\mathrm{pH}$ gradient, using a 500-ml mixing chamber. The reservoir, with $0.01 \mathrm{~m}$ acetate buffer $(\mathrm{pH}$ 5.0 ), was tightly connected to the mixing chamber. Pooled active fractions were frozen and stored at $-25^{\circ} \mathrm{C}$. About $150 \mathrm{mg}$ of the purified enzyme was obtained.

Enzyme characterization. Isoelectric focusing ${ }^{23)}$ was done on an LKB column $(110 \mathrm{ml})$ containing $1 \%$ carrier ampholite (Ampholine) with a $\mathrm{pH}$ from 3.5 to 5.0. The phoresis was at $450 \mathrm{~V}$ for $48 \mathrm{hr}$ at about $4{ }^{\circ} \mathrm{C}$.
PAGE was done by the standard pore formation of Davis at $\mathrm{pH} 9.4 .^{24)}$ SDS-PAGE was run as described by Weber and Osborn, ${ }^{25)}$ using gel with a crosslinkage of $10 \%$. Protein bands in the gel were stained with Coomassie Brilliant Blue R-250, and carbohydrate bands with periodic acid-Schiff reagent prepared by the method of Zacharius et al. ${ }^{26)}$

The antiserum to $A$. oryzae acid CPase O-1, that was produced on solid bran culture was prepared as described previously. ${ }^{6)}$

The molecular weight was measured by the gel filtration method described previously. ${ }^{6)}$ The SDS-polyacrylamide gel method of Weber and Osborn ${ }^{25}$ was also used. Proteins of known molecular weight served as reference markers.

The CD spectrum was measured with a JASCO J-20A automatic recording spectropolarimeter at room temperature and a $1 \mathrm{~mm}$ pathlength quartz cell in the ultraviolet region, extrema between 200 and $250 \mathrm{~nm}$.

FPLC was done on a column of Mono Q. After injection of $500 \mu \mathrm{l}$ of the samples, elution was done at a flow rate of $2.0 \mathrm{ml} / \mathrm{min}$ with $0 \sim 0.2 \mathrm{M} \mathrm{NaCl}$ containing $0.01 \mathrm{M}$ acetate buffer ( $\mathrm{pH} 5.0$ ).

Sequential release of $\mathrm{C}$-terminal amino acid residues from peptides and measurement of kinetic parameters were done as previously described. ${ }^{6)}$

\section{RESULTS}

In a 30-liter jar fermentor, the maximum specific activity $\left(1 \mathrm{nkat} / \mathrm{ml} / A_{280 \mathrm{~nm}}\right)$ was obtained after $72 \mathrm{hr}$ of inoculation at $30^{\circ} \mathrm{C}$. When cultivation was done for $96 \mathrm{hr}$, ninhydrin-positive materials increased and the specific activity decreased. When the aeration was changed from $10 \mathrm{liter} / \mathrm{min}$ and $400 \mathrm{rpm}$ to $5 \mathrm{liter} / \mathrm{min}$ and $300 \mathrm{rpm}$, the enzyme production was not affected. The CPase activity from DEAE-Sephadex, CM-Sephadex, and the final SP-Sephadex were each eluted as a

Table I. Purification of $155 \mathrm{~K} A$. oryzae Acid CPase O

\begin{tabular}{|c|c|c|c|c|c|}
\hline Fraction & $\begin{array}{l}\text { Total activity } \\
\quad(n \text { kat })\end{array}$ & $\begin{array}{l}\text { Volume } \\
\text { (ml) }\end{array}$ & $\begin{array}{l}\text { Specific activity } \\
\text { (kat/kg protein) }\end{array}$ & $\begin{array}{l}\text { Yield } \\
(\%)\end{array}$ & $\begin{array}{l}\text { Purification } \\
\text { (-fold) }\end{array}$ \\
\hline Culture filtrate & 165,850 & 15,500 & 0.00161 & 100 & 1 \\
\hline $\begin{array}{l}\text { Extract from } \\
\text { ethanol precipitate }\end{array}$ & 143,350 & 1,600 & 0.0587 & 86 & 36 \\
\hline DEAE-Sephadex eluate & 126,592 & 920 & 0.206 & 76 & 128 \\
\hline CM-Sephadex eluate & 101,360 & 1,120 & 0.343 & 61 & 213 \\
\hline SP-Sephadex eluate & 74,825 & 275 & 0.502 & 45 & 312 \\
\hline
\end{tabular}


Table II. Some Enzymatic and Physicochemical Properties of $115 \mathrm{~K}$ A. oryzae ACID CPASE O

\begin{tabular}{lccc}
\hline & \multicolumn{3}{c}{ Acid CPases from A. oryzae } \\
\cline { 2 - 4 } Properties & $\mathrm{O}$ & $\mathrm{O}^{a}$ & $\mathrm{O}^{a}-2^{a}$ \\
\hline Culture method & Submerged & Koji & Koji \\
Molecular weight by & & & $63 \mathrm{~K}$ \\
$\quad$ Gel filtration & $155 \mathrm{~K}$ & $63 \mathrm{~K}$ & - \\
$\quad$ SDS-PAGE & $73 \mathrm{~K}$ & $61 \mathrm{~K}$ & 4.18 \\
Isoelectric point & 4.37 & 4.08 & - \\
$E_{1 \mathrm{~cm}, 280 \mathrm{~nm}}^{1 \%}$ & 18.8 & 18.9 & - \\
$\mathrm{CD} \lambda_{\max }$ nm & 210 & - & 0.393 \\
$\quad[\theta]_{\max }$ & 9800 & 0.394 & 3.7 \\
Specific activity & & & \\
Optimum pH for & 0.502 & 3.7 & $5 \sim 6$ \\
hydrolysis of Z-Glu-Tyr & 3.7 & $5 \sim 6$ & 0 \\
pH stability & $5 \sim 6$ & 0 & 0 \\
Residual activity $(\%)$ at & & 0 & PMSF (78) \\
pH 3.0 and $50^{\circ} \mathrm{C}$ & 84 & PMSF (77) & IAA (100) \\
pH 4.5 and $60^{\circ} \mathrm{C}$ & 63 & IAA (100) & \\
Inhibitor & PMSF (40) & &
\end{tabular}

a Data from ref. 6 .

$b$ Standard substrate used was Z-Glu-Tyr. Specific activity towards Z-Glu-Tyr is expressed as katal/kg protein.

c The enzyme was incubated with $1 \mathrm{~mm}$ inhibitor at $\mathrm{pH} 3.7$ for $10 \mathrm{~min}$ and the residual activity was measured at pH 3.7.

single peak when the enzyme was purified from submerged culture broth. Purified enzyme was stable for at least six months at $-25^{\circ} \mathrm{C}$. Results of the purification are summarized in Table I.

The purified enzyme preparation gave a single band on PAGE at $\mathrm{pH} 9.4$ and SDSPAGE as shown in Fig. 1. The enzyme gave a single peak on isoelectric focusing with an isoelectric point of 4.37. Further experiment with FPLC also showed a single symmetrical peak of the enzyme. We concluded that the enzyme was homogeneous.

Based on Sephadex G-200 gel filtration studies, the molecular weight of the enzyme from submerged culture broth was about $155 \mathrm{~K}$ in the presence of $0.2 \mathrm{M} \mathrm{NaCl}$. When the purified enzyme was electrophoresed in SDS polyacrylamide gel with or without mercaptoethanol, a single band with molecular weight $73 \mathrm{~K}$ was obtained. Carbohydrate staining of the gel showed a band with exactly the same migration rate as that of the protein

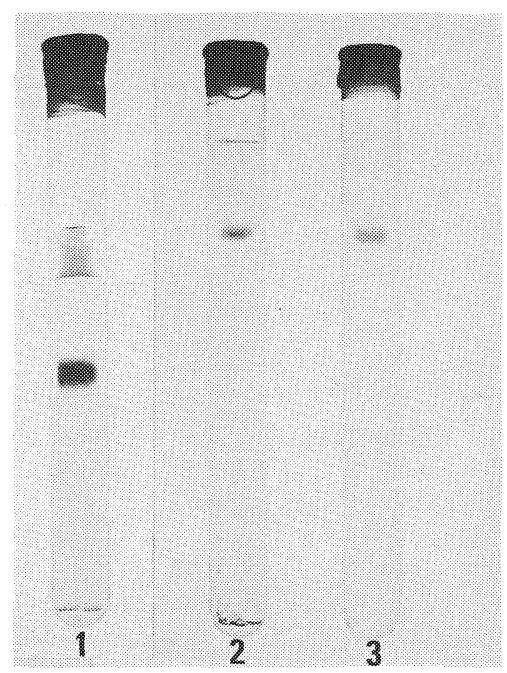

FIG. 1. PAGE and SDS-PAGE of the Final Preparation of $155 \mathrm{~K}$ A. oryzae Acid CPase O.

1, PAGE was done in $7.5 \%$ gel at $\mathrm{pH} \mathrm{9.4;2}$ and 3, SDSPAGE was done in $10 \%$ gel with an enzyme preparation treated with $1 \% \operatorname{SDS}$ in the presence of $1 \%$ mercaptoethanol at room temperature overnight.

Slots $1(15.3 \mu \mathrm{g}$ protein) and $2(10.2 \mu \mathrm{g}$ protein $)$ stained with Coomassie Brilliant Blue, slot 3 (10.2 $\mu \mathrm{g}$ protein) stained with periodic acid-Schiff reagent. 


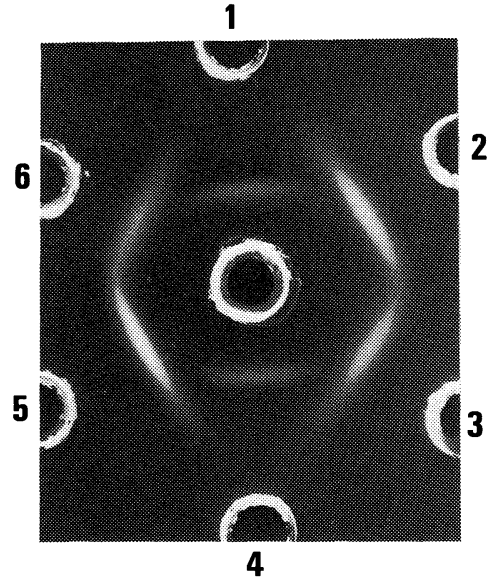

FIG. 2. Immunodiffusion Cross-reactivity of Antiserum Raised against Acid CPase O-1 and 155K Acid CPase O.

Center well, antiserum to acid CPase O-1; 1 and 4, 155K acid CPase O; 2 and 5, acid CPase O-1; 3 and 6, acid CPase $\mathrm{O}-2$.

Table III. Relative Rate of Hydrolysis For A. oryzae AcID CPASES ON A RANGE OF PEPTIDES

\begin{tabular}{|c|c|c|c|}
\hline \multirow{3}{*}{ Peptide $^{a}$} & \multicolumn{3}{|c|}{ Relative activity ${ }^{b}(\%)$} \\
\hline & \multicolumn{3}{|c|}{ Acid CPases from A. oryzae } \\
\hline & $\mathrm{O}$ & $\mathrm{O}-1^{\mathrm{c}}$ & $\mathrm{O}-2^{c}$ \\
\hline Z-Glu-Tyr & 100 & 100 & 100 \\
\hline Z-Tyr-Leu & 233 & 98 & 97 \\
\hline Z-Tyr-D-Leu & 0 & 0 & 0 \\
\hline Z-Gly-Pro-Leu-Gly & 11 & 65 & 61 \\
\hline Z-Val-Glu & 23 & - & - \\
\hline Bz-Gly-His-Leu & 7.8 & 0.4 & 0.5 \\
\hline Z-Gly-Leu & 6.7 & 4 & 4 \\
\hline Z-Gly-Lys & 2.6 & 7 & 8 \\
\hline Z-Gly-Phe & 7.5 & Trace & Trace \\
\hline Z-Gly-Pro-Leu-Gly-Pro & 0.2 & Trace & Trace \\
\hline Z-Gly-Pro & Trace & Trace & Trace \\
\hline Z-Gly-Pro-Leu & 0.03 & 4 & 2 \\
\hline Z-Pro-Pro & 0 & 0 & 0 \\
\hline Tyr-Leu & 0.08 & - & - \\
\hline Glu-Glu & 0.04 & - & - \\
\hline
\end{tabular}

a Concentration of each substrate was $5 \times 10^{-4} \mathrm{M}$.

$b$ The enzyme reaction was done at $\mathrm{pH} 3.7$ and $30^{\circ} \mathrm{C}$. Relative activities were expressed as percentages of the activity toward Z-Glu-Tyr.

c Data in ref. 6 . -, not measured.

band. The enzyme must therefore be a glycoprotein.

Some catalytic and physical properties of
Table IV. Release of C-Terminal Amino Acid Residues from Proangiotensin ( $18.5 \mathrm{nmol}$ ) AND BRADYKININ $(22 \mathrm{nmol})$ AT pH 3.7 AND $30^{\circ} \mathrm{C}$ BY $155 \mathrm{~K} A$. oryzae ACID CPASE O

\begin{tabular}{|c|c|c|c|c|c|}
\hline \multirow{3}{*}{$\begin{array}{c}\text { Released } \\
\text { amino acid } \\
\text { from: }\end{array}$} & \multicolumn{5}{|c|}{$\begin{array}{c}\text { Released amino acid by } 155 \mathrm{~K} \text { A. oryzae } \\
\text { acid CPase } \mathrm{O}^{a}(\mathrm{nmol})^{b}\end{array}$} \\
\hline & \multicolumn{5}{|c|}{ Incubation time (hr) } \\
\hline & 1 & 3.5 & 6 & 24 & 48 \\
\hline \multicolumn{6}{|c|}{ Proangiotensin $^{c}$} \\
\hline Leu & 17.9 & 18.2 & 18.1 & 18.0 & 18.5 \\
\hline His & 12.4 & 16.9 & 17.4 & 17.4 & 19.5 \\
\hline Phe & 0.6 & 4.0 & 6.3 & 15.6 & 18.6 \\
\hline Pro & 0 & 0 & 0 & 1.5 & 5.9 \\
\hline Ile & 0 & 0 & 0 & 0.2 & 0.9 \\
\hline Tyr & 0 & 0 & 0 & 0 & 0.4 \\
\hline Val & 0 & 0 & 0 & 0 & 0.3 \\
\hline Arg & 0 & 0 & 0 & 0 & trace \\
\hline Asp & 0 & 0 & 0 & 0 & trace \\
\hline \multicolumn{6}{|c|}{ Bradykinin $^{d}$} \\
\hline Arg & 21.6 & 21.8 & 21.9 & 22.3 & 22.3 \\
\hline Phe & 0.9 & 4.5 & 7.4 & 24.4 & 39.6 \\
\hline Pro & 0 & 1.4 & 3.4 & 14.1 & 24.4 \\
\hline Ser & 0 & 1.4 & 2.9 & 12.1 & 20.5 \\
\hline Gly & 0 & 0 & 0 & 0 & 0.1 \\
\hline
\end{tabular}

a 50 pkat of $155 \mathrm{~K}$ A. oryzae acid CPase $\mathrm{O}$ was used.

$b$ The released amino acids were analyzed on an automatic amino acid analyzer by the previously described method. ${ }^{6}$ )

c The amino acid sequence of proangiotensin is Asp-Arg-Val-Tyr-Ile-His-Pro-Phe-His-Leu.

${ }^{d}$ The amino acid sequence of bradykinin is Arg-ProPro-Gly-Phe-Ser-Pro-Phe-Arg.

the enzyme are summarized in Table II. The optimum $\mathrm{pH}$ of the enzyme for Z-Glu-Tyr was 3.7. At pH $2.5 \sim 3.5$, the enzyme had still above $50 \%$ activity of the maximum activity. Enzymatic activity was inhibited by TPCK, ZPCK, and PMSF but not by IAA, PCMB, EDTA, or S-PI. $\mathrm{NaCl}$ at high concentration $(20 \%)$ caused about $30 \%$ inhibition of the enzyme activity measured with Z-Glu-Tyr as a substrate.

Immunodiffusion studies showed a spur formation between the $155 \mathrm{~K}$ acid CPase $\mathrm{O}$ and low molecular acid CPase O-1 (Fig. 2).

The relative hydrolysis rates of a series of peptides by the enzyme are shown in Table III. The enzyme splits off neutral and basic amino 
Table V. Kinetic Parameters $155 \mathrm{~K}$ A. oryzae Acid CPase O toward Angiotensin, BradyKinin, AND Z-Glu-Tyr AT 3.7 and $30^{\circ} \mathrm{C}$

\begin{tabular}{|c|c|c|c|c|c|c|c|c|c|}
\hline \multirow{2}{*}{$\begin{array}{l}\text { Substrate } \\
\text { Subsite }^{a} \\
-\mathrm{P}_{2}-\mathrm{P}_{1}-\mathrm{P}_{1}^{\prime}\end{array}$} & \multicolumn{3}{|c|}{ CPase O } & \multicolumn{3}{|c|}{ CPase O- $1^{b}$} & \multicolumn{3}{|c|}{ CPase O- $2^{b}$} \\
\hline & $\begin{array}{l}k_{\mathrm{cat}} \\
\left(\mathrm{s}^{-1}\right)\end{array}$ & $\begin{array}{c}\mathrm{Km} \\
(\mathrm{mm})\end{array}$ & $\begin{array}{c}k_{\text {cat }} / K m \\
\left(\mathrm{~s}^{-1} \cdot \mathrm{mM}^{-1}\right)\end{array}$ & $\begin{array}{l}k_{\text {cat }} \\
\left(\mathrm{s}^{-1}\right)\end{array}$ & $\begin{array}{c}\mathrm{Km} \\
(\mathrm{mM})\end{array}$ & $\begin{array}{c}k_{\text {cat }} / K m \\
\left(\mathrm{~s}^{-1} \cdot \mathrm{mM}^{-1}\right)\end{array}$ & $\begin{array}{l}k_{\mathrm{cat}} \\
\left(\mathrm{s}^{-1}\right)\end{array}$ & $\begin{array}{c}K m \\
(\mathrm{~mm})\end{array}$ & $\begin{array}{c}k_{\text {cat }} / K m \\
\left(\mathrm{~s}^{-1} \cdot \mathrm{mM}^{-1}\right)\end{array}$ \\
\hline $\begin{array}{l}\text { Angiotensin } \\
-\mathrm{His}^{6}-\mathrm{Pro}^{7}-\mathrm{Phe}^{8}\end{array}$ & 0.34 & 0.1 & 3.4 & 1.7 & 0.2 & 8.5 & 0.15 & 0.09 & 1.7 \\
\hline $\begin{array}{l}\text { Bradykinin } \\
\quad-\text { Pro }^{7}-\mathrm{Phe}^{8}-\mathrm{Arg}^{9}\end{array}$ & 14.7 & 0.06 & 245 & 19 & 0.05 & 380 & 24 & 0.07 & 367 \\
\hline $\begin{array}{l}\text { Synthetic peptide } \\
\text { Z-Glu-Tyr }\end{array}$ & 86 & 0.48 & 179.2 & 53 & 0.5 & 106 & 51 & 0.5 & 102 \\
\hline
\end{tabular}

${ }^{a}$ Residues in peptide are numbered according to Schechter and Berger. ${ }^{27)}$

$b$ Data in ref. 6 .

$\downarrow$, indicates split bond.

acids from the substrate but not D-amino acids in the terminal position. Z-Tyr-Leu was the best substrate for the enzyme in the experiment. The substrate specificity for $N$ acyl-peptides of the enzyme resembles that of the acid CPase from A. saitoi. ${ }^{1}$

The data in Table IV indicate that the $155 \mathrm{~K}$ acid CPase $\mathrm{O}$ from $A$. oryzae removes neutral and basic amino acids as well as proline from the C-terminal position of proangiotensin and bradykinin at $\mathrm{pH}$ 3.7. No indication of endopeptidase activity could be detected, nor was any release of free amino acids by autodigestion of the enzyme detected after a prolonged period of incubation. When proangiotensin with proline at the penultimate position was used as a substrate, the $\mathrm{C}$ terminal phenylalanine was released slowly by the enzyme. A small amount of proline, which occupies the fourth position from the $\mathrm{C}$ terminus, could first be detected after the incubation for $24 \mathrm{hr}$. On the other hand, with bradykinin, proline at the third position from the $\mathrm{C}$-terminus was first detected after $3.5 \mathrm{hr}$.

Kinetic parameters of the $155 \mathrm{~K}$ acid CPase $\mathrm{O}$ of angiotensin, bradykinin, and Z-Glu-Tyr are summarized in Table $V$. Initial rates towards angiotensin and bradykinin were measured at $\mathrm{pH}$ 3.7. To obtain the kcat values for hydrolysis of the C-terminal peptide bond of the substrates, the released C-terminal amino acid was analyzed by an automatic amino acid analyzer. No amino acids other than the C-terminal amino acid from the substrate were observed. The $155 \mathrm{~K}$ acid CPase $\mathrm{O}$ and low molecular weight acid CPases from $A$. oryzae had similar values of $K m$ and $k_{\text {cat }}$ in the hydrolysis of the $\mathrm{C}$-terminal of bradykinin and Z-Glu-Tyr at $\mathrm{pH} 3.7$ and $30^{\circ} \mathrm{C}^{6}{ }^{6}$ When proline was present at the penultimate position from the $\mathrm{C}$-terminus as in angiotensin, the value of $k_{\text {cat }}$ of the $155 \mathrm{~K}$ acid CPase $\mathrm{O}$ was larger than that of low molecular weight acid CPase $\mathrm{O}-2$ but smaller than that of acid CPase O- $1 .{ }^{6}$

\section{DISCUSSION}

In our previous paper we reported that $A$. oryzae IAM 2640 produced two forms of acid CPase in solid bran medium; the enzymes were termed $A$. oryzae acid CPase O-1 and O-2, both with molecular weights of $63 \mathrm{~K}$. In this paper we found that an $155 \mathrm{~K}$ molecular weight acid CPase was produced exclusively in the liquid medium of $5 \%$ rice bran by $A$. oryzae IAM 2640. When $A$. oryzae IAM 2640 was grown in liquid medium at $\mathrm{pH} 4.5$, little acid proteinase was produced; consequently, acid CPase could be easily purified to homogeneity. The $155 \mathrm{~K}$ acid CPase $\mathrm{O}$ and low molecular weight acid CPases had the same $\mathrm{pH}$ stability 
and $\mathrm{pH}$ optimum for Z-Glu-Tyr, but they were distinguishable by their molecular weight and certain enzymatic and physicochemical properties. ${ }^{6)}$ To examine whether $155 \mathrm{~K}$ acid CPase $\mathrm{O}$ was the same structure as low molecular weight acid CPase, an immunological study was done. $155 \mathrm{~K}$ acid CPase $\mathrm{O}$ shared an antigen with low molecular weight acid CPase O1. Thus these enzymes are at least partly homologous.

When the purified $155 \mathrm{~K}$ acid CPase $\mathrm{O}$ was electrophoresed in SDS polyacrylamide gel with or without mercaptoethanol, a single band with molecular weight aroud $73 \mathrm{~K}$ was obtained, indicating that the enzyme from submerged culture broth was composed of two similar monomers. Since no mercaptoethanol was required, the dimer formation was noncovalent and did not involve the cysteine residues. Our previous study ${ }^{6}$ ) showed that the value of $k_{\text {cat }}$ for angiotensin markedly differs between acid CPase O-1 and O-2. The value of $155 \mathrm{~K}$ acid CPase was intermediate between the value of acid CPase O-1 and O-2.

$155 \mathrm{~K}$ acid CPase $\mathrm{O}$ seems to be less dependent on the sulfhydryl group than is low molecular weight acid CPase; concentrations of PCMB and IAA that inhibit $80 \sim 100 \%$ of low molecular weight acid CPase activity produce only $1 \sim 15 \%$ inhibition of $155 \mathrm{~K}$ acid CPase $\mathrm{O}$ activity. The active center of $155 \mathrm{~K}$ acid CPase $\mathrm{O}$ may be slightly different structurally.

Acknowledgments. This research was supported in part by a Grant-in-Aid for Reserch Council from the Ministry of Agriculture, Forestry and Fisheries of Japan, as an original and creative research project in biotechnology. We thank Dr. Y. Narahashi of Riken (The institute of Physical and Chemical Research) for the operation of the CD.

\section{REFERENCES}

1) E. Ichishima, Biochim. Biophys. Acta, 258, 274 (1972).

2) E. Ichishima and T. Arai, Biochim. Biophys. Acta, 293, 444 (1973).

3) E. Ichishima, S. Sonoki, K. Hirai, Y. Torii and S. Yokoyama, J. Biochem., 72, 1045 (1972).
4) E. Ichishima, A. Yamane, T. Nitta, M. Kinoshita, S. Nikkuni, T. Oka and S. Yokoyama, Appl. Microbiol., 26, 327 (1973).

5) M. Takeuchi, T. Ushijima and E. Ichishima, Agric. Biol. Chem., 36, 1259 (1972).

6) M. Takeuchi, T. Ushijima and E. Ichishima, Curr. Microbiol., 7, 19 (1982).

7) S. Yokoyama and E. Ichishima, Agric. Biol. Chem., 36, 1259 (1972).

8) S. Yokoyama, A. Oobayashi, O. Tanabe, S. Sugawara, E. Araki and E. Ichishima, Appl. Microbiol., 28, 953 (1974).

9) S. Yokoyama, A. Oobayashi, O. Tanabe and E. Ichishima, Appl. Microbiol., 28, 742 (1975).

10) S. Yokoyama, A. Oobayashi, O. Tanabe and E. Ichishima, Biochim. Biophys. Acta, 397, 443 (1975).

11) T. Hofmann, "Methods in Enzymology," Vol. 45, ed. by L. Lorand, Academic Press, New York, 1976, p. 587.

12) E. Ichishima, M. Takeuchi, K. Yamamoto, Y. Sano and T. Kikuchi, Curr. Microbiol., 1, 95 (1978).

13) R. Hayashi, "Methods in Enzymology," Vol. 45, ed. by L. Lorand, Academic Press, New York, 1976, p. 568.

14) D. Siepen, P. Yu and M. Kula, Eur. J. Biochem., 56, 271 (1975).

15) E. Ichishima, K. Yoshimura and K. Tomoda, Phytochemistry, 22, 825 (1983).

16) H. Zuber, "Methods in Enzymology," Vol. 45, ed. by L. Lorand, Academic Press, New York, 1976, p. 561.

17) Y. Kubota, S. Shoji and T. Funakoshi, J. Biochem., 74, 757 (1972).

18) K. Visuri, J. Mikola and T.-M. Enari, Eur. J. Biochem., 7, 193 (1969).

19) W. F. Carey and J. R. E. Wells, J. Biol. Chem., 247, 5573 (1972).

20) H. Umetsu, A. Abe, Y. Sugawara, T. Nakai, S. Watanabe and E. Ichishima, Food Chem., 7, 125 (1981).

21) K. Sakaguchi and K. Yamada, Nippon Nôgeikagaku Kaishi, 20, 65 (1944).

22) M. Florkin and E. H. Stotz, "Comprehensive Biochemistry," Vol. 13, ed. by M. Florkin and E. H. Stotz, Elsevier, Amsterdam, 1973, p. 26.

23) O. Vesterberg, "Methods in Enzymology," Vol. 22, ed. by W. B. Jakoby, Academic Press, New York, 1971, p. 398.

24) O. Gabriel, "Methods in Enzymology," Vol. 22, ed. by W. B. Jakoby, Academic Press, New York, 1971, p. 565 .

25) K. Weber and M. Osborn, J. Biol. Chem., 244, 4406 (1969).

26) R. M. Zacharius, T. E. Zell, J. H. Morrison and J. J. Woodlock, Anal. Biochem., 30, 148 (1969).

27) I. Schechter and A.Berger, Biochem. Biophys. Res. Commun., 27, 157 (1967). 